\title{
Fundamentals of Islamic Finance and Easy Access to Credit
}

\author{
Ousmane Diomande \\ Training and Research Unit in Economics and Management (TRU-EM) of the Felix Houphouët Boigny University, Abidjan, \\ Côte d'Ivoire \\ Email: ousm2003@yahoo.fr
}

How to cite this paper: Diomande, $\mathrm{O}$ (2020). Fundamentals of Islamic Finance and Easy Access to Credit. Theoretical Economics Letters, 10, 978-996.

https://doi.org/10.4236/tel.2020.104057

Received: July 12, 2020

Accepted: August 28, 2020

Published: August 31, 2020

Copyright (c) 2020 by author(s) and Scientific Research Publishing Inc. This work is licensed under the Creative Commons Attribution International License (CC BY 4.0).

http://creativecommons.org/licenses/by/4.0/

\begin{abstract}
Our study therefore aims to inform and raise awareness of the advantages of Islamic finance with a view to an effective financial inclusion policy in Côte d'Ivoire. This consists of making known the fundamentals of Islamic finance by identifying the different sources of Sharia and their positioning in the Islamic legislative system. In addition, in terms of Islamic financial products, our choice is made on the Mudharaba contract which seems to us better suited particularly to the concerns of small entrepreneurs who struggle to have financing for their projects, because of the many constraints imposed by traditional financial institutions. For our analysis, we first used the results of the experiences of the Islamic Development Bank (IDB) around the world. In addition, data were also used from the International Monetary Fund (IMF), the World Banks (BM), Islamic Financial Services Board (IFSB), documentary research on all 57 member countries of the IDB including Côte d'Ivoire. Ultimately, it appears that conventional banking practices have shown that credit conditions are difficult to meet and interest rates high. This makes it difficult for the middle classes and private entrepreneurs to access legal sources of finance.
\end{abstract}

\section{Keywords}

Islamic Finance, Islamic Banking, Classic Finance, Credit

\section{Introduction}

Islamic finance is a finance that bans commercial and financial transactions containing clauses deemed questionable or unfair. It advocates humanism in business in accordance with the rules laid down by Muslim religious texts. This finance which wants to be socially responsible, has its own regulation, its ethical and moral particularities compared to classical finance. Its large financing ca- 
pacity makes it for developing countries a niche to explore, with a view to diversifying their sources of investment and accelerating financial inclusion and the development of small entrepreneurs excluded from the traditional financial system. However, some regulatory and legal adaptations, such as those initiated by the Central Bank of West African States (BCEAO) in 2018 (BCEAO, 2018a), are necessary to create a favorable framework for the establishment of Islamic financial institutions in order to improve people's access to finance.

Knowledge of Islamic finance has improved considerably with numerous works published on the subject since the last generalized economic crisis of 2008. In fact, it was around this time that Islamic finance aroused the interest of scholars due to its growing influence. Among others, we have a study by (Imane \& Bouchra, 2011) on the resistance of Islamic finance to the crisis of autumn 2008. A capacity, according to them, has aroused the interest of researchers and specialists on the issue of Islamic finance. Imam and Kpodar (2015) analysed on the link between the development of Islamic banks and economic growth in lowand middle-income countries over the period 1990-2010. Their result shows a definite advantage for these countries insofar as the development of Islamic finance is positively correlated with economic growth. Other works such as that of Lila (2011) attempt to inform about the ethical nature of Islamic finance while pointing out its significant development over the past 50 years. According to (Reuters, 2019), Islamic financial institutions and windows around the world numbered 1389 in 2017. At the academic level, research and training are also making progress with 688 educational bodies and 2564 research papers produced on the subject of Islamic finance between 2015-2017, when there was only one, the only bank in 1960, the Mit Ghamr savings bank. An increase probably due to the alternative solutions was proposed to the difficulties engendered by the classic financial system.

Indeed, it is difficult, if not impossible, for a certain category of low-income population, considered insolvent in the eyes of banks and microcredit structures, to benefit from credit if it is not on almost unbearable conditions. The high cost of credit associated with the many difficult conditions surrounding it has ended up excluding many households from the conventional financial system.

In these conditions, Islamic finance, which presents a new kind of financial products freed from the interest rate and based on the sharing of risks and profits according to the sources of Islamic law, is comparable to a pole tense to a person who drowns.

Speaking of Islamic finance, however, it is not an image, but a reality that has already proven itself in other countries. If this is the case, why should Côte d'Ivoire, which is already using this new source of financing on international markets, not favor its establishment on the national territory in order to facilitate access to financing for millions to people still excluded from the traditional financial system?

In this paper, our focus has shifted to conventional banks on credit condi- 
tions, interest rates and access to finance for the lower income classes. For Islamic finance we are interested in its foundations, the principle of profit and loss sharing, the prohibition of interest rates and speculation and the use of the Mudharaba contract in support of private entrepreneurship.

But before, it is for us in our study to consider how Côte d'Ivoire, as much as other countries like Malaysia or England, can benefit from Islamic finance after having understood the operation and basic rules. To this end, we first present Islamic finance, then we review the sources behind its rules, followed by its essential principles. Finally, we will discuss access to Islamic credit, without forgetting to mention the Riba known as interest or usury and the Mudharaba contract that can foster the spirit of entrepreneurship among low-income populations.

\section{Literature Review}

\subsection{Islamic Finance}

According to Alioui et al. (2015) is designated as Islamic finance, all financial and commercial activities which respect the principles of Islamic law and jurisprudence, commonly referred to as Sharia, the Arabic word which literally means "path".

It is understood that Islamic finance only contemplates in the Sharia the rules relating to commercial transactions and economic activity. The main rule in this area, around which the growing mechanisms, institutions and products of Islamic finance are organized, is the principle of permission to trade. Prohibitions in commerce are only exceptions. The law in question comes from a set of texts called sources of law or sources of "Sharia".

\subsection{Sources of Sharia}

In terms of law, the rules of modern Islamic finance are the product of fiqh (law science or jurisprudence) and Usul al-figh ${ }^{1}$ (roots of law). According to (Bleuchot, 2000), the fiqh translated simply as "Muslim law" is technically the knowledge (ilm ${ }^{2}$, or science) of ahkâm (statutes of human acts) by means of clues (adilla, scriptural evidence). It is a practical science, as opposed to theology, which is a theoretical science. As for Usul al-fiqh, these are the science of principles (qawâ'id, rules), by which we can deduce fiqh. It is the science of evidence (scriptural and others) that led to the solutions developed in the branches of law. So it's like the methodology of a job to do. The usûl al-fiqh of this fact essentially constitutes the justification of the positions, supported by references drawn from the sources of the law (Sharia).

According to Alioui et al. (2015), the Sharia, through principles and recommendations, defines and describes, in all areas, the behavior of Muslims. It

${ }^{1}$ Refer to Institute of Islamic Banking and Insurance (IIBI), https://www.islamic-banking.com/explore/glossary/glossary-financial-terms-u.

${ }^{2}$ Refer to Institute of Islamic Banking and Insurance (IIBI),

https://www.islamic-banking.com/explore/glossary/glossary-financial-terms-i. 
therefore governs the spiritual, social, moral and ethical dimension of the Muslim in the private sphere, but also in the public sphere, including in particular economic and commercial activities.

Sharia law includes both religious dogmas, "al'Aquida", and everything related to being and its social relationships, "al-Mu'amalat". As a result, the rules of Islamic Finance also come from the four main sources of sharia that are, in order of predominance, the Quran, Sunnah, Al-Ijma, and Qiyas.

\subsection{Quran}

Economics is the study of the rational behavior of the economic man (homo economicus) whose actions are aimed at satisfying his personal interest. In this perspective, producer and consumer, each aspiring to prosperity and economic well-being, will use different techniques. Maximizing production and minimizing costs is the profit maximization strategy for the producer, while maximizing utility will be the concern of the consumer. These are fundamental assumptions of traditional economics allowing the definition of a simple model of human behavior outside the ethical and religious field. Conversely, in Islamic finance and in Islamic economics of which it is a part, as Ibn Khaldun (1377) thought, moral guidance helps to eliminate mutual rivalries, strengthens social solidarity, and creates a door (inclination) towards justice (Al-Mawardi, 1882) by relegating according to (Chapra, 2000) "personal interest in a long-term perspective going beyond the life of this world and reaching life after death". It is a theoretical foundation inspired by the Quran which is the primary source of Muslim law. Essentially divine, the Quran serves as a reference for all other sources of law whose authenticity is judged according to their conformity with the holy book. With an original text in Arabic, the Quran was transmitted to Prophet Muhammad (Peace and Blessings be upon him) through the Archangel Gabriel (Jibril). It includes 114 suras (chapters) each consisting of ayyates (verses) intended to guide humanity. Its recitation in prayers conditions the validity of Muslim worship. It contains, beyond worship (Ibâdât), prescriptions on social life in all its areas called: (Mou'âmalât).

According to Benali (2017), in modern usage, the term Mou'âmalât covers the following areas of Law, with the number of verses relating to said areas: personal status (70), civil law (70), criminal law (30), defense law (13), constitutional law (10), international law (25), business and finance law (10). You should know that it happens that the Quran does not deal with certain subjects at all or only addresses the main principles whose explanation is supplemented by the Sunnah.

It is reported that when Prophet Muhammad (SAW) wanted to send Mu'haz Boun Djabal to announce the message of Islam to Yemen, He asked him what he would judge if necessary, according to the Book of God (Quran) replied Mou'haz. What if you don't find (an explicit solution) in the Book of God?-I will then judge according to the Sunnah of the Messenger of God, replied Mou'haz. What if you don't find (an explicit solution) in the Sunnah of the 
Messenger of God? I will then make an effort of reflection (ijtihâd) to form an opinion, replied Mou'haz. What the Prophet (SAW) approved ${ }^{3}$.

\subsection{Sunnah}

Sunnah, etymologically means path, way and contextually, it is the perfect example of the Prophet Muhammad (Peace and Blessings of God on Him): PBGH. As such, it is the source, which, hierarchically, comes after the Quran. In practice, it designates the sayings (Sunnah kawliyat), facts (Sunnah fi'iliyat), practices (Sunnah fi'iliyat), recommendations and appreciations of the Prophet Muhammad (Sunnah taqririyat) conveyed by the hadiths.

A hadith is therefore a story relating to the sayings, facts, practices, recommendations and assessments of the Prophet Muhammad (PBGH) serving as a model for Muslims. The authenticity of the chain of transmission makes the hadith mandatory and makes it the vehicle of the Sunnah, the second source of law in Islam. The safest collection of hadiths are Al-Bukhari and Muslim.

The Sunnah, although an indirect revelation remains a sacred source because the behavior of the Prophet (PBGH) is the manifestation of the divine will and supports the first source of law, the Quran. This is why; the authentic Sunnah is an infallible and obligatory source as much as the Quran.

To verify this authenticity, the jurists will analyze the Hadiths by first separating them into two parts: the chain of transmission from the Prophet (PBGH) to the last reporter, called "Isnad" and the content containing the substantive rule called "Matn". It is a true science that will rank the hadiths in order of authority, according to whether they are weak, good and authentic. Only hadiths with no imperfections are declared authentic.

However, when the first two sources of law do not provide a solution to a problem, it is possible to have recourse to the complementary sources of law, which are "Al-Ijma" and "A-Qiyas" as derivatives of sacred sources and fruits of intellectual efforts of Muslim jurists.

\subsection{Al-Ijma}

"Al-Ijma", an Arabic word translated by consensus, expresses the convergence or unanimity between Muslim jurists on a legal opinion. In fact, it is an authentic reference of third importance on legal questions. In practice, when a legal case arises at a given time, and all the ulama of the same time after the Prophet's death (PBGH) agree to pronounce the same opinion on this case, their agreement is called: "Al-Ijma". The judgment resulting from this consensus acquires the status of law. Such judgments can serve as a reference for other later judgments by analogy: "A-Qiyas".

\subsection{Qiyas}

A-Qiyas or reasoning by analogy is the fourth source of Muslim law. This rea-

${ }^{3}$ Report reported by At-Tirmidhî and Abû Dâoûd and A'lâm ul-muwaqqi'în, tome 1 pp. 49-50. 
soning is used, when it comes to a legal case not mentioned in religious texts. The legal case is then compared to another roughly analogous case because of a common underlying characteristic, for which a prescription is given in the texts. It is used because the rule of law concerning the latter case could not be clearly identified entirely apart.

An example of this is the drunkenness ban. In practice, it is impossible to name by name all the substances which, when consumed, cause the same effects as alcohol. On this basis, A-Qiyas allows lawyers to declare unlawful any goods the consumption of which would have the same effects as alcohol. The analogy is therefore based on a common reason for the judgment. Given the speed of the changes that we face in our world known as globalized in general and in the field of modern finance in particular, A-Qiyas, although resulting from human rationality prone to error, remains a source of important legislation for new legal questions for which there are no clear explanatory elements in the Quran and in the Sunnah.

From this point of view, A-Qiyas in the process of formation of Muslim law constitutes for Juris consults, holders of legal knowledge and the capacity to create, adapt and develop the law, a formidable tool for the exercise of human reason in the establishment of complementary rules of law, in accordance with the Quran and the Sunnah. These rules organize commercial and financial behavior, and guide them towards compliance with the basic principles relating to justice, fairness, transparency and the mutual consent of the contractors.

\section{Principles}

The principles of Islamic finance to which we allude in this study relate to the sharing of profits and losses and the control of the Sharia board.

\subsection{Sharing of Profit and Loss}

The sharing of losses and profits is the distribution key in a partnership contract. This distribution is not made on the basis of a guaranteed profit at the signing of the financing contract. Clearly, the funder cannot derive any benefit from its financing, unless the investor agrees to share the associated risks. However, an advantage freely granted by the borrower after repayment of the loan and without constituting an implied or explicit condition is not considered illegal. To protect the interests of clients and borrowers of Islamic financial institutions a Sharia board is required.

\subsection{Sharia Board Guarantors of Islamic Products}

The Sharia board is a council of Muslim jurisconsults (Sharia scholars), specialists in commercial jurisprudence (Fiqh Al-Mouamalat), finance and/or economics with skills in banking matters and a good knowledge of the four legal schools (Mazahib) of the Islam, whose opinions remain subject to the Quran and the teachings of Prophet Muhammad (PBGH). The schools in question are those 
founded by:

- Abu Hanifa (80-150/703-767) called the Hanafi school, predominant in the Near East, Central Asia and the Indian subcontinent, notably Pakistan, Turkey, ...;

- Ahmad ibn Hanbal (164-241/778-855) known as the Hanbalite school, strongly represented in the Middle East, especially Saudi Arabia and the Gulf countries;

- Mâlik (93-179/717-801) named Malikite school, influential in the United Arab Emirates, in North Africa and in the Sahel countries, in particular Côte d'Ivoire, Senegal, Mali, Mauritania, Morocco, Algeria, Tunisia, Libya, ...;

- Shafei (150-204/769-820) designated Shafeite school, popular in East Africa, Yemen and Southeast Asia, especially Malaysia.

The sharia board has a role of regulating the activities of Islamic financial institutions. In this capacity, he advises and assists Islamic financial institutions in matters of Sharia compliance of their financial products and operations. Based on product characteristics and legal documentation, the sharia board verifies the sincerity, integrity, fairness and legality of matters submitted for its assessment. In its control, it attaches great importance to risk factors, such as the degree of uncertainty. Its opinions called "Fatwa" are opposable to the recipient institutions. Such Fatwa are contained in periodic reports intended to confirm or deny the Sharia compatibility of the financial products and operations of Islamic financial institutions.

The presence of the Sharia board alongside conventional management bodies is a sine qua non for the credibility of any financial institution (Bank or Insurance) which claims to distribute Islamic financial products. In its operation, the Sharia board meets periodically to examine and approve Sharia compliance for operations and the products offered by a financial institution. To this end, it plays a role of control over all of the establishment's activities.

According to Pajolec (2009) "The keystone of Islamic finance as currently practiced rests on the essential role of appreciation of the Sharia Boards, with which each Islamic banking institution is endowed, and whose role of exegesis, of expertise and interpretation, contributes to the ex-ante validation of transactions, as well as to the dissemination and standardization of Islamic Finance wherever it is practiced."

In general, as pointed out (Moore, 1997), before authorizing a product, beyond legality, the Sharia board asks the following questions:

- Do the terms of the transaction comply with Sharia law?

- Is it the best investment for the client?

- Will the proposed investment produce added-value for the client? For the community? For the society in which the client is active?

- As a fund manager, would the bank carry out the transaction in the same way as it would if it were acting on its own account?

Any negative answer to one of these questions should lead according to Ka- 
rich (2002) to a refusal of authorization by the Sharia board. As is the case for any investment relating to prohibited and illicit sectors according to the foundations of Islamic finance.

\subsection{Prohibition of Illegal Investment Sectors}

The investment sectors in which Islamic finance cannot intervene are as follows:

- The tobacco industry;

- Pornography;

- The alcohol, wine and drug industry;

- The gambling industry;

- The pig and illicit food industry;

- The arms industry for individuals except states;

- The classic banking industry;

- The classic insurance industry;

- The entertainment industry that disregards morality.

It is obvious that in Islamic finance, one cannot neither sell nor buy illicit goods and services because of the moral requirements which govern this finance. On the contrary, households are encouraged to opt for halal or legal activities or expenditure. Consequently, Islamic finance protects them against the exploitation and abuse of the strongest who hold wealth by guaranteeing them access to credit on bearable conditions.

As for conventional banks and decentralized financial structures, their loans are inaccessible due to the inability of the middle class to produce guarantees fulfilling the conditions giving access to financing. Thus, we are witnessing a weak banking use with a rate of $17.7 \%$ in 2017 according to information note $\mathrm{N}^{\circ}$ 56 of the BCEAO (2018b) in the 4th quarter 2018, while in the same year the Ivorian authorities estimated the penetration rate microfinance at $6 \%$. In addition, to the insurmountable conditions for low-income populations, there are the high interest rates of banks and conventional microfinance institutions.

Indeed, the legal interest rate of the BCEAO varies since 2016 between 2.5 and $4.5 \%$. However, for microfinance institutions in the eight countries of the West African Economic and Monetary Union (WAEMU), this rate is capped at $24 \%$, according to a union decision that came into force on January 1, 2014. All of these constraints contribute to complicating access to credit in Côte d'Ivoire. For some, the alternative to this situation is the use of loan sharks, known by the nickname "margouillats", thereby defying the danger of precariousness and insolvency due to exorbitant usurious rates.

This kind of difficulty, which the populations, very often intellectuals, are confronted with, is perhaps not foreign to the development in the time of Islamic finance.

\section{Developmental Characteristics of Islamic Finance}

Commerce is an old activity that was practiced in the Middle East long before 
the advent of Islam. Having become Muslims, this culture of commerce at the origin of their frequent trips has, according to Benedikt (2014), favored their contribution to the propagation of capitalism and globalization. However, Islamic Finance as we know it today originated in the 1940s, following a series of articles published by Dr Muhammad Hamidullah in 1936, titled "The Islamic Solution to Fundamental Economic Problems-The Position of work", Sayyid Manazir Ahsan Gilani in 1947 on "Islamic economics", Abul Ala Mawdudi, the same year on "The economic problem of man and his Islamic solution" and Uzair Ahmad in 1950 under the title "Overview of operations banking without interest". The idea having thus germinated through the first contemporary writings has not stopped evolving to this day.

\subsection{Growth of Islamic Financial Assets}

Modern Islamic finance, of some 100 billion dollars at the end of the 90s according to Shabsigh et al. (2017) invested 951 billion dollars of assets in 2008, an increase of $25 \%$ compared to 2007 when the total was 758 billion dollars recorded and in 2009 its outstanding amount reached 1000 billion dollars. At that time, the Islamic banking system had almost covered the predominantly Muslim countries and their potential is now of interest to players all over the world.

In its 2018 State of the World Islamic Economy report, Thomson Reuters, based on data for member states of the Organization of Islamic Cooperation, estimates that the average annual growth rate of Islamic finance assets has been by 6\% since 2012 with 1900 billion dollars in 2017 in 50 Muslim and non-Muslim countries around the world. According to Mughal (2019), this boom in the Islamic financial market, which reached $\$ 2440$ billion in assets in 2018, was accompanied by the widening of the scope of Islamic finance, from commerce to industry, including real estate and banking. And the forecasts that exist point to better days for the development in progress. Indeed, the prospects for the growth of Islamic financial assets are substantial due to the economic and socio-political changes in the countries of the Organization of Islamic Cooperation (OIC) and their volume could, according to the Standard \& Poor's 2012 report, reach more of $\$ 4.5$ trillion by the end of 2020 and $\$ 3.8$ trillion in assets by 2023 according to Reuters (2019). That is to say a projected average annual growth of $10 \%$ at the global level.

\subsection{Global Representativeness of Islamic Finance}

While the existence of Islamic trade-related principles and practices dates back more than 1440 years, their application to modern finance is recent. A realization that will crescendo in view of the distance traveled with Islamic finance currently scattered over the five continents.

\subsubsection{Middle East}

The dominant region of Islamic finance is the Middle East where the Islamic 
Development Bank (IDB) was born. Other institutions have been created in support of the latter, to promote the emergence of this investment management system, respectful of Islamic values. The products offered to consumers continue to expand with the performance and variety of Middle Eastern Islamic institutions. According to a ranking of the top 10 most successful Islamic institutions in the world, published in 2018 by Global Finance Magazine, 70\% of these, or seven (07) out of ten (10), are from this region.

\subsubsection{Asia}

In Asia, Malaysia is at the forefront with a developed Islamic financial system in terms of banks, Takaful and Sukuk. After her, follow other countries like Brunei, Indonesia, Pakistan, Philippines, Thailand, ...

In these countries, the seriousness of Islamic banks has finally been convinced. Over time, they develop and adapt their products so that non-Muslim customers seek their services. The Malaysian case is a lesson in this matter, insofar as in some Islamic banks in the country half of the registered customers are not Muslim.

\subsubsection{Europe}

In recent decades, the growth of Islamic finance has reached double-digit rates. However, this growth is not limited to Muslim countries. On the contrary, it is the work of actors including States, companies or businesspersons... even in Europe where Islamic finance is welcomed with attitudes varying from country to country. As with any subject, there is a mixture of indifference, ignorance, hesitation and interest. The UK, for example, has become the capital of Islamic finance in Europe, due to a political will to attract as much Islamic capital as possible to London. At the same time, other countries like France are still hesitant. According to reports from the Kuwait Finance House, Islamic banking assets in December 2014 on European soil represented $0.5 \%$ of total assets, or even $20 \%$ if we add Islamic funds domiciled in European jurisdictions. Despite the fragmentation and limitations observed, it seems that things will gradually improve because of the successes observed in the markets of countries using the sukuk such as Luxembourg, the United Kingdom etc.

\subsubsection{America}

In the United States, there are many Islamic institutions, among others Al Manzil Islamic Financial Services of New York created in 1998, American Finance House Lariba created in 1987, Albaraka Bancorp of California created in 1987, Albaraka Bancorp of Texas created 1987, Albaraka Bancorp of Chicago established in 1989 and University Islamic Financial Corporation of Southfield, Michigan established in 2007. But, we are interested in BNY Mellon Asset Servicing, declared best Islamic custodian in 2017. This institution, a subsidiary of the Bank of New York (Bank of New York), was created in 1998 to provide custody and management solutions to the world's major institutional investors, in- 
cluding Sharia-compliant funds. It has a large global franchise with $\$ 33.3$ billion in assets in custody or administration, operating in over 100 markets. Behind the United States, Canada and Australia have also established Islamic institutions under national law.

\subsubsection{Africa}

In Africa generally, Islamic banks have started to take hold on the continent. This is the case for example of the Islamic Bank of Senegal (BIS) in 1982, a year later, the Islamic Bank of Guinea Conakry (BIG) and the Islamic Bank of Niger (BIN), on the ashes of Massraf Faycal Al Islami Niger (MFAI), are born. In the Maghreb countries and in Egypt Islamic banks exist, as well as in Sudan where the financial system is completely Islamic. However, this presence in Africa on the scale of the 54 African countries remains derisory. To fill their budget deficits, more and more states of the continent have decided to turn to Islamic finance. Senegal, Ivory Coast, and Togo took turns trying to raise a total of 1.2 billion euros in Islamic financial markets between 2014 and 2016. We can expect the multiplication of such initiatives to keep pace with the economic development and financial inclusion needs of a large segment of the African population excluded from the conventional financial system, particularly in Côte d'Ivoire.

\section{Access to Islamic Credit}

To facilitate access to credit, Islamic finance is based first of all on raising the awareness of individuals with the capacity to finance their responsibility towards God, in relation to the wealth of which they are the depositaries.

\subsection{Proprietorship}

In Islam the right to private property is a right of enjoyment and transfer, it being understood that absolute property belongs to God whose man is the vicar on earth. The latter as a depositary has relative sovereignty over the natural and material resources that he has been able to accumulate and of which he will have to account to God. This is what is pointed out (Causse-Broquet, 2007) when citing among the main characteristics of Islamic economic theory the lieutenancy of goods and work ethics.

However, before men the right to lawfully acquired property is a right guaranteed and declared sacred to any individual, whether male, female, Muslim, non-Muslim, regardless of color, race or social status. The owner of a good is simply called to be grateful to God by being generous with what He has granted him, while avoiding disobedience, debauchery and waste. Any action on his part must be in the middle ground between exaggerated individualism and unjust collectivism.

Indeed, the man in his capacity of "lieutenant" has the duty, after having taken the necessary precautions not to lose his wealth, to fruit it through business initiatives or the support for projects carried by other people looking for fund- 
ing. His action, beyond the advantages that he can derive from it, must aim for "a balanced satisfaction of the material and spiritual needs of the human personality" (Jouini \& Pastré, 2008). In other words, beyond business, his investment, taking into account the ethical dimension of work, serves the general interest. Because, work is supposed to create added value which gives right to property, wealth and prevents hoarding.

In addition, it should be noted that money in the Islamic financial system is considered both as a unit of measure and as a means of exchange. It is therefore not an object that is sold or rented, because in itself, it has no value. Therefore, it should not be hoarded, but rather used primarily to facilitate trade and commerce. Consequently, profit is only legitimized if an effort has been induced in its acquisition. So, "Any fructification of any capital, any acquisition of wealth must imperatively come from the deployment of an effort, whether individual or collective, from an exchange or a gift, or even from an inheritance, considered as the only legitimate sources of value creation" (Karich, 2002).

In essence, money cannot create value simply by the passage of time without the associated action of physical capital, or labor. Clearly, you cannot claim any interest (riba) simply by having loaned money if you are not even at risk in the object of the loan. This eliminates the high interest rates imposed, by banks and decentralized financial structures of the traditional system, on low-income households seeking financing or a loan.

\subsection{Ban on Riba}

Riba: etymologically means surplus, commonly translated by wear, interest. Jouini \& Pastré (2008) declare that Riba as fixed remuneration, "function only of the passage of time, and completely disconnected from the real profitability of the underlying investment project, is contrary to Muslim ethics, because considered as socially destructive."

The Quran proclaims the prohibition of Riba and encourages believers to abstain from it. This shows that this practice existed during the time of Prophet Muhammad (PBGH). Martens (2001) notes that a common practice in the business community of that time, when the borrower or the buyer on credit had difficulties in repaying its debt, was to double the maturity period of the principal due, but at the cost of doubling the interest rate. This way of doing things is called Riba al-jahiliya, or Riba (of the period) of ignorance, in reference to the pre-Islamic era. According to Chouraqui (1990), it is to this practice that God mentions in verse 130 of the Surah of the family of Imran, that He proclaims: "O believers! Do not practice usury by excessively multiplying your capital. And fear Allah so that you will succeed!".

This is the place to point out that contrary to what certain non-Muslim authors seem to believe, we do not believe that the Islamic religious texts were decreed by the Prophet Muhammad (PBGH) himself, but rather teachings for the good-to be creatures, coming from Almighty God through Djibril (angel Ga- 
briel). On this subject, the Quran says in Surah 53: An-Najm (the star), verses 2 to 5: "(The Prophet Muhammad) Your companion did not go astray and was not misled, and he pronounces nothing under the effect of passion; This (what he says) is nothing more than an inspired revelation taught him [The Angel Gabriel] with prodigious strength."

To return to the subject, it is therefore the Quran, in Surah 2: AL-BAQUARA (THE COW), Verses 275 and 279, and the Sunnah who have declared Riba unlawful (Haram). Hence the qualification of Islamic finance as "La-riba", that is to say a finance which rejects Riba. Therefore, beyond charity, anyone wishing to take advantage of a commercial relationship must behave like an entrepreneur and share the risks and the benefits. This principle constitutes an invitation to avoid the surplus of credits paid for the use of borrowed capital (Riba al-qurûd) or even Riba at term (Riba an-nasiah) which is an amount paid in return for a rescheduling in the payment of a debt.

According to Saadallah (1992), at the doctrinal level, some have tried to distinguish the interest of Riba and thus to give legitimacy to the practice of interest. However, the consensus of Muslim jurists, as expressed by the resolutions of the fiqh academies, firmly rejects any distinction between interest and Riba. In fact, Sharia law prohibits any contractual premium on the amount of a loan of fungible goods (including currency). This researcher explains some reasons which, according to him, explain the prohibition of interest. He cites in particular the fact of constituting contractual remuneration known in advance, of remunerating the time which should not be the subject of exchange and of guaranteeing remuneration of the lender, when the risks are fully assumed by the borrower. Note that these are the risks linked to the result of the activity financed by the loan and not the risk of default, which remains the responsibility of the creditor, but against which he can protect himself by requiring appropriate guarantees.

On this subject the Quran, in Surah 2: Al-Baquara (The cow), verse 275, responds to those who confuse Riba and trade and says: "They say: Trade is quite like interest, whereas God made trade lawful, and illicit interest". It is therefore an invitation to respect the rules of fairness in business and, if necessary, to substitute the loan of honor (Qard-Hassan) for loan sharking so as not to abuse the weakness of others. The Quran highly recommends it in Sura 2: Al-Baquara (The Cow), verse 245 in these terms: "Whoever lends to God with good grace, He will make it multiplied for him several times." The act encouraged in this passage is the graceful loan which gives up the interest which constitutes the principal remuneration of the capital borrowed in traditional finance. This is a concern already addressed by other revealed religions.

\subsubsection{Riba among Jews and Christians}

The existence of the prohibition of Riba seems, according to Martens (2001), to be signaled in the Jewish Torah at the level of the Pentateuch of the Old Testa- 
ment, in Exodus (chapter 22, verse 25) and Leviticus (chapter 25, verses 34 to 46). In the passages indicated, the practice of usury would have been condemned through the prohibition of the "tarbit", a Hebrew word which would mean both usury and interest. However, Jews would have been more selective than Muslims in enforcing this ban. Thus, the tarbit ban was a reality in relations between Jews, while it was ignored in affairs with non-Jews.

After Judaism, the practice of usury and interest-bearing lending would also have been discouraged by the Church on the basis of the Gospel according to Luke (chapter 6, verses 34 and 35) in the New Testament (Lapidus, 1987). In 1312, the bishops of France, meeting in council, even threatened with excommunication those who lent at interest and also the lords who allowed them. This concern for interest seems to have gone beyond the religious framework and interested the economists themselves.

\subsubsection{Debates between Economists around the Riba}

Beyond the religious field, Riba is a subject which has caused debates between economists. In 1787, Jeremie Bentham published a text with the evocative title, "Defense of Usury", opposing Adam Smith who, although father of "Let do and let pass, the world goes on by itself!", was in favor of a ceiling of interest rates (De Roover, 1955; Spiegel, 1987).

The ban on interest-bearing loans was finally abolished from canon law in 1830 (Reed and Bekar, 1997). The only thing that remains in our secular societies is the stigma attached to usury itself, as in Canada, the Criminal Code of which stipulates, in section 347 , that it is illegal to lend at an annual interest rate (nominal) greater than 60\%. This release allowed Riba's practice to evolve in various forms in modern societies, some of which are prohibited and others which are permitted by secular law.

\subsubsection{Modern Riba}

In modern West African societies and particularly in Côte d'Ivoire, usurious practices are a specialty of crooked businessmen, nicknamed "margouillats". They are mostly located in Abidjan, the Ivorian economic capital, in the Plateau, the business district. Workers in the formal sector who find it difficult to cope with their family responsibilities are generally the first victims of margouillats.

When a worker in difficulty requests their financial assistance, the margouillats circumvent the law and make up their usurious practice by an act of sale of frontage. In fact, the latter, who regularly hold shops selling various articles, give cash to the borrower and record the transaction in the form of a sale on credit of goods, but at a higher amount than the loan granted. As collateral for the loan, they collect the debtor's bank credit card and all related information. So, the margouillats in collusion with certain bank agents access the accounts of their victims whom they empty each month until the debt is exhausted, while the latter and their families languish in misery.

Such an act is not authorized either by Islamic finance or by secular law, it is 
in no way different from the subversive practices of the former usurers who used tricks or hiyâl in Arabic (Khawam, 1976) to circumvent the ban on Riba.

The method, known under the name of bay' al-ïna (double sale) or mukhâtara (from khatïr: dangerous, adventurous), consisted in sale on credit in which the good exchanged played only a purely fictitious role (Martens, 2001). However, he sold it at a price higher than the amount needed by the borrower, ie $100 \mathrm{di}$ nars, while the latter asked only 90 dinars. The 100 dinars were payable in time, one year. On the other hand, the lender immediately bought the property from the borrower by paying cash 90 dinars. In fact, the lender who kept the property, had transferred 90 dinars to the borrower and was guaranteed to receive from the latter 100 dinars after one year. In the strict sense, at least for the interested parties, there had been no loan at interest, but simply sale and repurchase of a property. It is for these reasons, Moore (1997) believes that "Riba is really the AIDS of contemporary economic activity, because it deprives economic life of its immunity and steals it from its capacity to fight against the disease of l "economy". This financial illness which overwhelms modest households in debt with the traditional financial system is aggravated by fuzzy closures or by complementary insurance contracts which they are not requesting at the time of the loan. All these unnecessary loads that benefit creditors at the expense of debtors are considered according to Islamic finance as unfair.

Once the limits and contours of financial and commercial relations have been generally defined according to Islamic finance, one must choose among Islamic contracts the one that is likely to facilitate access to finance for poor households. It is a difficult choice, because each type of contract has its comparative advantages, but as regards access to credit for low-income populations, we choose the Mudharaba contract which is a participatory contract with variable returns.

This type of contract seems to us more suitable for this study since it aims to cultivate entrepreneurship and resourcefulness. But instead we could have chosen Mucharaka, Mouzaraâ, Qard-Hassan, Zakat, Waqf or any other contract. This being the Mudharaba contract is a financial instrument which has the principle that in a transaction all the parties take part in the risk. So, the distribution of risks between the parties to the contract conditions their participation in the profit. This is the Profit and Loss Sharing (PLS) rule, also called "Al-Ghunm bil Ghurm", that is to say that there can be no remuneration without the risk involved.

\subsection{Mudharaba Contract}

The term Mudharaba, etymologically means risk taking. In Islamic finance, it is a trust contract which links financial capital, intended for a project, provided entirely by an investor "Rabul-mal", generally the bank and working capital in the form of expertise and know-how provided by an entrepreneur "Mudharib" in order to carry out the funded project and improve it. As in the limited partnership, the administration of the project is the sole responsibility of the beneficiary 
while the capital received remains the property of the "lessor". The net profits, after having withdrawn the capital and the management costs of the entrepreneur, are shared according to proportions agreed in advance in the contract binding the parties. However, in case of loss, the entrepreneur will have lost his working time without any compensation while the disappearance of the capital is chargeable to the lessor, unless this disappearance results from negligence or non-compliance with the terms of the manager's contract.

We therefore note that the Mudharaba contract does not offer any income guarantee beforehand, thus exposing the actors to the risks of losses and profits linked to the project, with a different functioning from that of the limited partnership in a situation of involuntary loss.

In the context of poor families, the Mudharaba contract could be used to link two complementary factors: the capital factor ready to finance a project or converted into goods intended for sale and the labor factor which makes it possible to create wealth on the basis of capital employed. It is important to specify that in the practice of Mudharaba, Islamic banks admit the pooling of resources from several depositors to finance projects or activities.

It can therefore be a financial intermediation in which the banks receive the funds and by subrogation finance projects, economic activities in the form of mudharaba, while guaranteeing to each investor a part of the profits that the end user of the funds would realize.

In this form of Mudharaba, the management of liabilities and assets confers a double role on Islamic banks. On the one hand when it comes to liabilities, they behave like entrepreneurs "Mudharib" and manage deposits on behalf of clients and on the other hand, when we are on the asset side, they behave like of investors "Rabul-mal" and allocate the resources collected in consideration of the profitability potential of the projects without taking into account the creditworthiness of the applicants.

Anything that obliges banks to develop an internal mechanism of control and supervision of the activities and projects financed. Beyond that, the applicant aware that his remuneration is closely linked to the performance of his project is forced to manage the funds entrusted to him as well as possible.

In addition, the "Mudharaba" contract contributes to reducing the degree of risk to which the investors are exposed, insofar as while authorizing the collection of profits, oblige all the participants to share the possible losses. This contributes to the suppression of speculation and derivative products, the essence of which is to deal with ghost assets.

Adopting such simple principles can therefore help avoid the heightened volatility of the financial, commodity and food markets, as well as the subprime crisis linked to sovereign debt.

On this subject, the economist (Santi, 2019) asserts that "finance accessible to all and products whose understanding is within the reach of all: this is what Islamic finance can today bring to decadent westernized finance. Because money 
and finance are only a vector, not the ultimate goal". However, losses arising from the negligence or violation of Mudharaba's conditions by the contractor are the sole responsibility of the latter.

For it to be valid, the Mudharaba contract must contain clear and precise information on:

- The amount of capital contributions from each party, whether in cash or in kind. Contributions in kind subject to appraisal by expertise in accordance with the provisions of ordinary law;

- The methods and dates of making Mudharaba's capital available;

- The period covered by the Mudharaba and the possibilities of extension to maturity;

- The rights and duties of the parties, in particular the frequency of reporting, reports detailing the use of capital in accordance with the terms of the contract between the parties;

- The guarantees to be provided by the entrepreneur against any violation, fault or negligence on his part of the conditions of the Mudharaba contract likely to lead to the return of the capital to the Rab-al-Maal who brought it;

- The way of distributing Mudharaba profits, as a percentage of net profit, after deduction of charges and return of capital;

- The schedule for the distribution of profits agreed upon by the parties to the contract.

Furthermore, the clauses of the Mudharaba contract may provide for the possibility of excess profits and, if necessary, specify the methods of their allocation, if they exceed a determined threshold.

\section{Conclusion}

Islamic finance is based on rules of compliance with Sharia or Muslim law. Thus, Islamic financial institutions offer financial products that meet the standards enacted by Sharia. The main sources of Sharia in hierarchical order are the Quran, prophetic teachings (Sunnah), consensus between scholars (Al-Ijma) and reasoning by analogy (A-Qiyas).

Islamic finance, characterized by the application of standards from sources of Muslim law, is growing rapidly around the world, including in the most advanced countries. One of the peculiarities of this finance, which is to remove the bottlenecks of interest and abusive practices, may not be strange to its growth.

Indeed, for Islamic finance the accumulation of wealth is not an end in itself and man is only the depositary of goods whose absolute property belongs to God to whom he will have to account. He should not therefore seek to satisfy at all costs his desire for wealth by abusing the weak.

Rather, it must take into account its peers and be willing to support them in win-win partnerships through different types of Sharia-compliant contracts, including the Mudharaba. Hence the justification of commercial contracts deemed ethical allowing the poor to access credit on acceptable terms and, if necessary, 
to benefit from a loan without counterpart, called "Qard-Hassan".

However, it should be noted that our study's proposals for financial inclusion have a limited scope in the Ivorian context. Indeed, apart from the authorization of the BCEAO in 2018 opening the West African market to Islamic financial institutions, the country has not yet initiated internally the establishment of an adequate institutional and legal framework. Moreover, few people know of the very existence of this alternative solution that Islamic finance can offer.

Despite this insufficiency, isn't this the start of a new chapter in the bank-client or microfinance-client relationship? Only an effective establishment of Islamic banks and financial institutions in Côte d'Ivoire will allow us to respond.

\section{Conflicts of Interest}

The author declares no conflicts of interest regarding the publication of this paper.

\section{References}

Alioui, F. Z., Guellil, G., \& Soufyane, B. (2015). Islamic Finance, the Foundations of the System. Management Intercultural, 17, 6-11.

Al-Mawardi (1882). Adab al-Dunyawa al-Din (pp. 76-77). http://aljazi.org/rathath/Pdf/adabaldunya.pdf

Benali, A. (2017). The Four Sources of Muslim Law: The Koran. https://islam-references.org/les-quatre-sources-du-droit-musulman-le-coran-14

Benedikt, K. (2014). Early Islam and the Birth of Capitalism. $\square$

Bleuchot, H. (2000). Muslim Law.

Causse-Broquet, G. (2007). Why Take an Interest in Islamic Finance? The Point of View of a Teacher-Researcher. Revue du Financier, 166, 30-39.

Central Bank of West African States (BCEAO) (2018a). Banking Regulations: Instructions $n^{\circ}$ 002-03-2018, 003-03-2018, 004-05-2018 and 005-05-2018, March 21 and May 02, 2018. https://www.bceao.int/fr/reglementations/reglementation-bancaire

Central Bank of West African States (BCEAO) (2018b). Information Note $N^{\circ} 56$ of the $B C E A O$ in the 4th Quarter 2018 (p. 15).

https://www.bceao.int/sites/default/files/2019-02/Note\%20d\%27information\%20-\%20n \%C2\%B0\%2056\%2C\%204e\%20trimestre\%202018.pdf

Chapra, M. U. (2000). The Future of Economics: An Islamic Perspective.

Chouraqui, A. (1990). The Quran, Translation and Commentaries, 1990.

De Roover, R. (1955). New Perspectives on the History of Accounting. The Accounting Review, 30, 405-420.

Khaldun, I. (1377). Al-Muqaddimah (Introduction to History) (Translated by Franz Rosenthal, pp. 479-483).

Imam, P., \& Kpodar, K. (2015). Islamic Finance and Economic Growth: An Empirical Analysis. Development Economics Review, 23, 59-95. https://doi.org/10.3917/edd https://www.cairn.info/revue-d-economie-du-developpement-2015-1-page-59.htm

Imane, B., \& Bouchra, R. (2011). Beyond the Crisis. Is Islamic Finance a Means of Regu- 
lation? Public Ethics, 13, 7-8. http://journals.openedition.org/ethiquepublique/871 https://doi.org/10.4000/ethiquepublique.871

Jouini, E., \& Pastré, O. (2008). Challenges and Opportunities for the Development of Islamic Finance for the Paris Market: Ten Proposals to Collect 100 Billion Euros, Report of December 8, 2008.

Karich, I. (2002). The Islamic Financial System: From Religion to the Bank.

Khawam, R. R. (1976). The Book of Tricks the Political Strategy of the Arabs.

Lapidus, A. (1987). The Ownership of Money: Doctrine of Usury and Theory of Interest. Revue Économique, 6, 1095-1110. https://doi.org/10.3406/reco.1987.409026

Lila, G. S. (2011). Religion in Business: Islamic Finance.

Martens, A. (2001). Islamic Finance: Foundations, Theory and Reality.

Moore, P. (1997). Islamic Finance: A Partnership for Growth. London: Euromoney Publications.

Mughal, M. Z. (2019). Islamic Finance Assets Could Reach \$2.5 Trillion in 2019. https://www.agenceecofin.com/finance-islamique/1501-63208-les-actifs-de-la-finance-i slamique-pourraient-atteindre-2-500-milliards-de-dollars-en-2019

Pajolec, A. (2009). La finance islamique, contribution à l'émergence d'une éthique du XXIème siècle? Qualitique $\mathrm{n}^{\circ}$ 205, March 2009.

Reed, C. G., \& Bekar, C. T. (1997). Religious Prohibitions against Usury. Discussion Papers, dp97-07, Burnaby: Department of Economics, Simon Fraser University. https://ideas.repec.org/p/sfu/sfudps/dp97-07.html

Saadallah, R. (1992). Islamic Financing: Concept and General Principles, Seminar Proceedings No. 37 of the Islamic Development Bank (IDB) and of the Islamic Research and Training Institute (IRTI) on the Theme "Introduction to Islamic Financing Techniques”, 5-9 December 1992 in Nouakchott i.e. 11-15 Joumad-Thani 1413H.

Santi, M. (2019). Will the West Accept to Be Saved by Islamic Finance? https://www.latribune.fr/opinions/tribunes/l-occident-acceptera-t-il-d-etre-sauve-par-1 a-finance-islamique-803772.html

Shabsigh, G., Leckow, R., \& Zeidane, Z. (2017). IMF Approves Proposals for Islamic Banking. Posted on February 21, 2017 by the International Monetary Fund (IMF) Blog. https://www.imf.org/external/french/np/blog/2017/022117f.htm

Spiegel, H. W. (1987). Usury. In J. Eatwell, M. Milgate, \& P. Newman (Eds.), The New Palgrave: A Dictionary of Economic Theory and Doctrine (pp. 769-770). London: Macmillan.

Thomson Reuters (2019). Islamic Finance Development Report 2018: Islamic Finance Outlook (p. 5). 